\title{
Effect of different concentrations of corn starch and whey protein on the characteristics of biodegradable cup
}

\author{
Sonia, Talwar, G. 四, Kumar, N., Chawla, R., Wakchaure, N.
}

Received: 20.11.2020

Revised: 24.01.2021

Accepted: 01.02.2021

\begin{abstract}
An attempt was made to prepare a composite biodegradable cup using corn starch, whey protein, carboxymethyl cellulose and glycerol. For biodegradable cup formation, corn starch (5-7\%), WPC-35 (1.5-3\%), CMC (0.5-2\%) and glycerol (2$4 \%)$ range was selected. To decide upon temperature at which the cup forming solution attains final viscosity, samples were tested under rapid visco analyser to conclude that layering was enabled at $50^{\circ} \mathrm{C}$. Based on observations three best biodegradable cups combinations were selected Sample A (corn starch 7\%, WPC-35 3\%, Cellulose 2\%, glycerol 2.5\%); Sample B (corn starch 7\%, WPC-35 2\%, Cellulose 2\%, glycerol 2.5\%); Sample C (corn starch 7\%, WPC-35 3\%, Cellulose $2 \%$, glycerol $4.0 \%$ ). Properties like thickness, solubility, water vapour transmission rate, viscosity, moisture, lightness were studied for three samples to select the final cup. Based on observation, Sample C's final composition was selected as corn starch 7\%, WPC-35 3\%, cellulose $2 \%$, glycerol $4.0 \%$. The value for thickness, solubility, WVTR, moisture and lightness was observed as $0.5 \pm 0.025 \mathrm{~mm}, 48.50 \pm 0.66 \%, 1.14 \pm 0.086 \mathrm{~g} / \mathrm{m}^{2} / \mathrm{hr}, 7.74 \pm 0.16 \%, 41.96 \pm 1.86$ respectively. The lower diameter of the cup was observed as $5.5 \mathrm{~cm}$, upper diameter $7.5 \mathrm{~cm}$ and height of cup was observed as $4.0 \mathrm{~cm}$ with the capacity of the final cup as $55.5 \mathrm{ml} / 47.1 \mathrm{gm}$.
\end{abstract}

Key Words: Biodegradable cup, corn starch, moisture content, rapid visco analyser, water vapour permeability

\section{Introduction}

Packaging encompasses the protection and preservation of food and their raw material from deterioration as well as extends the self-stability. An augmented utilisation of synthetic packaging films has caused significant environmental issues, as it is completely non-biodegradable. A rising understanding of the healthier lifestyle has spurred research on novel strategies to prolong the food shelf stability without the application of preservatives. Due to environmental and disposal issues related to plastic waste, there is a need to develop an alternate edible and/or biodegradable films that can wholly or partially replace conventional synthetic polymers. Biodegradable packaging materials are usually derived from lipids, polysaccharides, proteins or their combination and can also act as a barrier for moisture, gas, flavourings as well as lipid, which improve the food consistency by reducing its degradation and thereby enhancing its shelf stability. Biodegradable packaging is eradicated to synthetic plastic packaging (Sain, 2020).

\section{Author's Address}

College of Dairy Science and Technology, GADVASU, Ludhiana

E-mail.: talwargopika@gmail.com
A significant advancement at the industrial level has been made with respect to the development of other forms of bio-based packaging material, on the basis of biotechnology, which contributes to economic growth. It is essential to define the biodegradability of these materials as far as the form of biodegradable and/or bio-based polymers is a concern. ASTM (1998) and ISO $(2005,2007)$ described the degraded materials as materials subject to substantial changes in the chemical structure under particular environmental conditions. Such alterations lead to degradations of mechanical and physical properties. Starch is an abundantly available material having a low cost that can be used in the production of degradable packaging materials and blend films that contain starch has pharmaceutical, agro-industrial and packaging applications (Lu et al., 2005). The combination of polyvinyl alcohol (PVA) with starch as a potential biodegradable polymer has been investigated by various researchers (Zhai et al., 2002; Zhai et al., 2003; Follain et al., 2005; Xiao and Yang, 2006). As per the extent of biodegradability, PVA can offer reliable support to starch films (Jayasekara et al., 2004). Starch is the most essential 
polysaccharide polymer that has been used in the formation of biodegradable films as it has the ability to form a continuous matrix (Lourdin et al., 1995). However in contrast to traditional synthetic polymers, starch has many drawbacks includes deprived mechanical properties and strong hydrophilic character (water sensitivity) (Averous and Boquillon, 2004), which makes it inadequate for certain applications specially packaging.

The plasticiser addition overcomes the brittleness of starch films and enhances the flexibility as well as extensibility. Addition of glycerol and sorbitol decreases the tensile strength, thus promoting film elongation (Laohakunjit and Noomhorn, 2004). On the other hand, whey protein helps in the formation of transparent, soft and elastic, water-insoluble films which gives good grease barrier and oxygen barrier properties at low humidity (Wang et al., 2010). Demirgoz et al. (2000) prepared film based material with cross-linking of corn starch and cellulose acetate. It was reported that film resulted in a reduced capacity to water sorption and slow rate of degradation in the aqueous medium as compared to other starch films. Till date, a lot of investigations have been carried on the development of biodegradable /edible films, but only a few research studies are available pertaining to biodegradable cups. The idea behind the development of a biodegradable cup was to develop a biodegradable container of certain shape so that it may replace the single-use plastic cups used in food packaging. Thus, keeping the above-mentioned research gaps in mind, a composite biodegradable cup was developed with corn starch, and whey protein concentrate-35 along with glycerol and Carboxymethyl cellulose (CMC) and the properties of the developed cup were investigated.

\section{Material and Methods}

\section{Selection of ingredients and their level}

In this investigation for the formation of the biodegradable cup, four ingredients were selected, i.e. corn starch (CS), Carboxymethyl cellulose (CMC), whey protein concentrate -35(WPC-35) and glycerol. Corn starch (CS) was purchased from, Central Drug House Pvt. Ltd. (product code 030261 batch no: 060616), India. CMC (Carboxymethyl Cellulose/ Cellulose Gum, 99.5\% of purity) was purchased from Central Drug
House (P) Ltd, product code 025791, Batch no: 060915 and AR grade. WPC-35- was purchased from Modern Dairy, Karnal. Glycerol was procured from Merck Specialties India. Based on preliminary trials, range for selected ingredients were decided to develop biodegradable cup and is as follows: Corn starch(5-8 \%), WPC-35-35 (1.5-3\%), CMC $(0.5-2.5 \%)$ and glycerol (2-4\%).

\section{Method for biodegradable cup formation}

Biodegradable cups were prepared by making modifications in the process which was used for film formation by Chandla et al. (2017). Filmogenic base solution was obtained by dispersion of corn starch, whey protein concentrate, CMC, all of these ranged from $5.0-8 \mathrm{~g} / 100 \mathrm{~mL}$, $1.5-3.0 \mathrm{~g} / 100 \mathrm{~mL}, 0.5-2.0 \mathrm{~g} / 100 \mathrm{~mL}$, respectively, with continuous stirring for $10 \mathrm{~min}$ in distilled water. The initial heating of starch powders in the water at $50^{\circ} \mathrm{C}$ with continuous stirring was carried out. Later on, carboxymethylcellulose was added to the starch solution. Glycerol (2.0-4.0 g/100 g starch), was incorporated as plasticiser and resulting dispersions were then heated to $90{ }^{\circ} \mathrm{C}$ for gelatinisation to occur. The resultant solution was cooled at room temperature $\left(50^{\circ} \mathrm{C}\right)$ to avoid the formation of air bubbles during pouring. Cups were formed with the help of the layering technique (layer by layer) in silicon cup purchased from the local market of Ludhiana, Punjab, India. The prepared filmforming solution was layered (manually with the help of a brush onto silicon cup. After each layer, the cup was placed in an oven at $60{ }^{\circ} \mathrm{C}$ till the layer dried up. Then the cup was pulled out from the oven, and another layer was added onto it. After drying the final layer, the cup was pulled, and the biodegradable cup was thus removed from the mould. These formed cups were kept in a desiccator at $30^{\circ} \mathrm{C}$ and $52 \%$ relative humidity, using saturated salt granules of magnesium nitrate $\mathrm{Mg}\left(\mathrm{NO}_{3}\right)_{2}$ prior to their characterisation (Chandla et al., 2017). The flow chart for the development of a biodegradable cup is given in the figure 1 .

\section{Viscosity measurement of rapid viscometer analyser}

Starch gelatinisation, pasting temperature, peak viscosity and were measured in the RVA (Model RVA-3C, Newport Scientific) supplied in the U.S. 


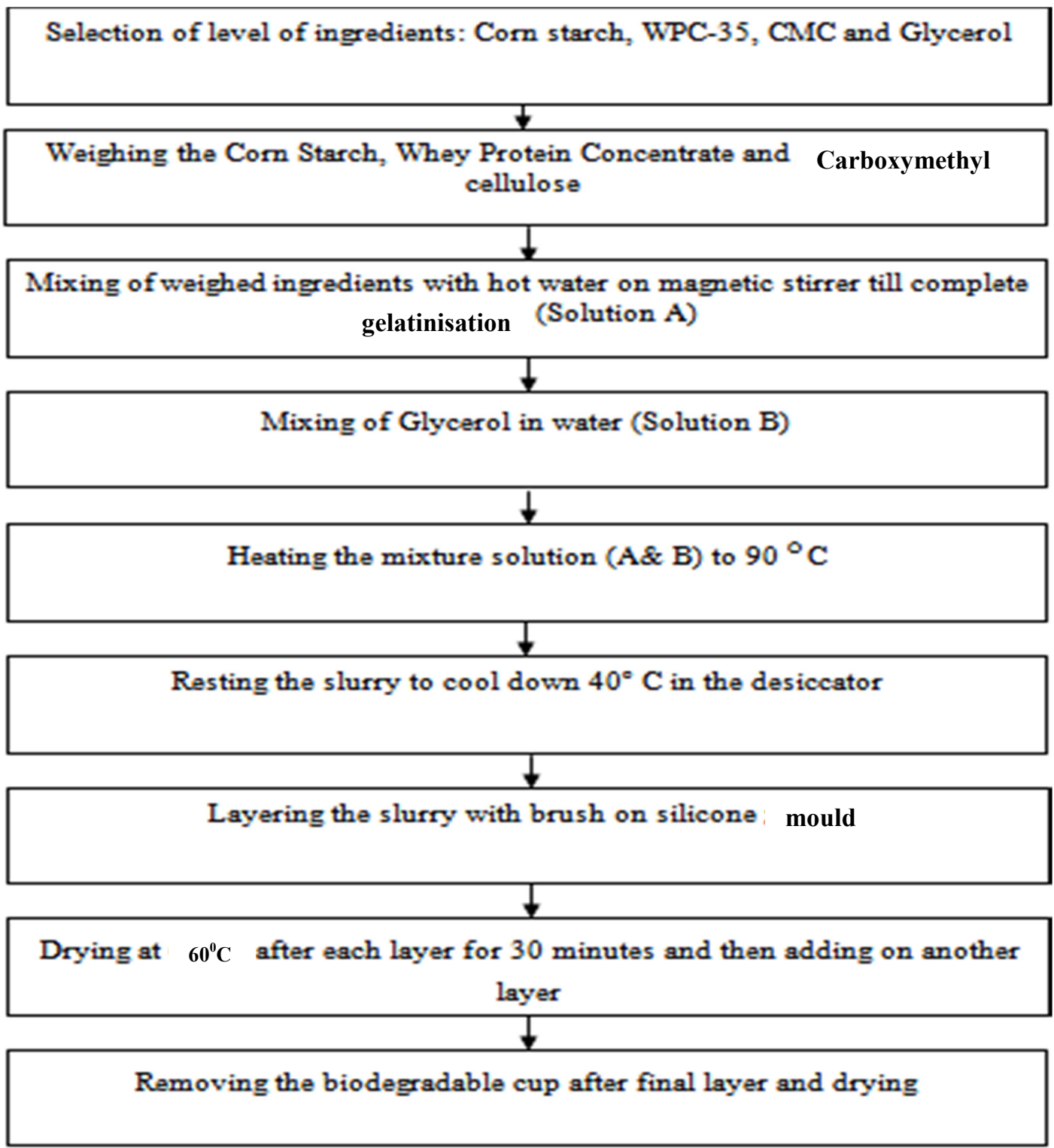

Figure 1. Flow chart for the procedure of biodegradable cup formation

by Foss Food Technology, Inc., Eden Prairie, MN with a $20 \mathrm{~min}$ test, equilibrating to $50^{\circ} \mathrm{C}$ for $2 \mathrm{~min}$, heating in $10 \mathrm{~min}$ to $95^{\circ} \mathrm{C}$ and cooling in $8 \mathrm{~min}$ to $50^{\circ} \mathrm{C}$. In order to make the total size of the sample $(28 \mathrm{~g})$, starch $(3 \mathrm{~g})$ was mixed with distilled water along with the addition of $0.5 \%, 1.5 \%$ of different gums and $1 \%$ concentration of starch. To distribute the sample and to eliminate lumps, 28-g of starch/gum suspension sample was discharged in a separate aluminium jar and manually stirred for 15 $30 \mathrm{~s}$ with the help of manually by spinning the plastic paddle. Then the paddle, sample and container were introduced into RVA instrument, and mixing of sample and water was prepared then after $1 \mathrm{~min}$ activation of test cycle was done.

\section{Measurement of physical properties}

\section{Color of biodegradable cup}

Colour analyses of film samples in terms of ' $\mathrm{L}$ ' (lightness) values were done using the Hunter colourimeter (Hunter Associates Laboratory Inc., Reston, VA., USA), which was standardized by black and white tiles before experimentation.

\section{Film thickness}

A digital micrometre (Mitutoyo 2046F, Japan) having a precision of $\pm 1 \mu \mathrm{m}$ was used to measure the thickness of the biodegradable cups. Three 
different positions on each film sample were chosen to estimate the film thickness and the average value was presented. Before testing, conditioning of the film samples was done for 48 hours at $25{ }^{\circ} \mathrm{C}$ and $50 \%$ relative humidity $(\mathrm{RH})$ in a humidity test chamber.

\section{Moisture content (MC)}

The standard method of AOAC (1994) was used to measure the $\mathrm{MC}$ of the biodegradable cups, in which known weight $(\sim 1.0 \mathrm{~g})$ pieces were dried at $120^{\circ} \mathrm{C}$, for around six $\mathrm{h}$ in an oven or till the alteration between two consecutive observations became constant. In each case, the experiment was carried out in three replications, and the average value was presented to minimise the experimental error. The following equation was used to calculate the $\mathrm{MC}$ and is expressed as $\% \mathrm{wb}$.

Moisture content $(\%)=\frac{\left(\mathrm{M}_{\mathrm{i}}-\mathrm{M}_{f}\right)}{\mathrm{M}_{\mathrm{i}}} \times 100$

Where;

$\mathrm{M}_{\mathrm{i}}=$ initial weight of the wet sample

$\mathrm{M}_{\mathrm{f}}=$ final weight of the dried sample

\section{Solubility}

The procedure proposed by Romero-Bastida et al. (2005) was used to estimate the solubility of the biodegradable cup in water. Concisely, rectangular samples of $20 \mathrm{~mm} \times 20 \mathrm{~mm}$ were cut out of the cups $(\mathrm{n}=3)$. The weight of the oven-dried sample $\left(105{ }^{\circ} \mathrm{C}\right.$ for $\left.24 \mathrm{~h}\right)$ was taken. Then the samples were dipped in distilled water at $25^{\circ} \mathrm{C}$ of $80 \mathrm{ml}$ and held for $1 \mathrm{~h}$ under slow agitation. After one $\mathrm{h}$, the swollen samples were taken out and again dried at $60{ }^{\circ} \mathrm{C}$ till the attainment of constant weight. Reduction in weight is measured as \% weight loss in $1 \mathrm{~h}$. The following equation was used to estimate the solubility.

Solubilty $(\%)=\frac{\mathrm{W}_{\mathrm{i}}-W_{f}}{\mathrm{Wi}} \times 100$

\section{Water vapour permeation}

The modified method of ASTM 96-00 was used to measure the water vapour permeability (WVP) of the films. Films samples were placed onto (as a covering on glass jar head surface) airtight glass jars containing anhydrous $\mathrm{CaCl}_{2}(0 \%, \mathrm{RH})$, and then kept in desiccators at $75 \% \mathrm{RH}$ (Souza et al., 2012). Modified gravimetric cup procedure was used to estimate the WVP of biodegradable films and variance of $75 \%$ RH was established ASTM, E 96/E96M-15 (2015). Initially, the films were sealed with sealant at the mouth of cups and kept in a controlled environmental chamber at $75 \% \mathrm{RH}$ and $30^{\circ} \mathrm{C}$. The migration of water vapour was estimated by a gain in weight of permeation, estimated after every $24 \mathrm{~h}$ for the period of 3 days. After every two $\mathrm{h}$, the weight of the films was recorded, and weight change was plotted against time. Linear regression technique was used to estimate the slope and used to calculate the water vapour transmission rates (WVTR). The WVP was estimated from the straight-line slope $(\mathrm{g} / \mathrm{s})$ divided by the transfer area $\left(\mathrm{m}^{2}\right)$. Following equation was used to determine the WVP.

$$
\mathrm{WVP}=\frac{\mathrm{WVTR}}{\mathrm{S}\left(\mathrm{R}_{1}-R_{2}\right)} \times \mathrm{d}
$$

Where: $\mathrm{S}$, is the saturation pressure of water $(\mathrm{Pa})$ at test temperature $\left(30^{\circ} \mathrm{C}\right), \mathrm{R}_{1}$ is the $\mathrm{RH}$ in the humidity chamber, $\mathrm{R}_{2}$ is the percentage $\mathrm{RH}$ in the cup and 'd' is the thickness (m) of film.

\section{Scanning electron microscopy}

Cups prepared (native and optimised) were fractured and suspended in the solvent. Further, it was kept on aluminium stub with the help of double-backed cellophane tape, coated in auto fine coater, JEOL-JFC-1600, through gold-palladium $(60: 40, \quad \mathrm{w} / \mathrm{w})$. Scanning electron microscope (SEM), JEOL, Tokyo, Japan, Model No. JSM 6610-LV was used to analyse the starch samples. At 5-6\% MC, absorption of film surface morphological characteristics was done. Different magnifications were used to analyse the starch samples. Prior to analysis, desiccator with silica gel $(\sim 0 \% \mathrm{RH})$ was used to store the film samples.

\section{Biodegradability}

The sample was studied in which sample A (corn starch 7\% + glycerol 3\%), sample B (whey protein concentrate $7 \%+$ glycerol 3\%), sample C (corn starch 7\% + Whey Protein Concentrate 3\%+ Carboxymethyl cellulose 2\% + Glycerol 2.5\%), sample D (corn starch 7\% + Whey Protein Concentrate $2 \%+$ Carboxymethyl cellulose $2 \%+$ Glycerol 2.5\%), Sample E (corn starch 7\% + Whey Protein Concentrate 3\% + Carboxymethyl cellulose $2 \%+$ Glycerol 4\%). The biodegradable samples of $2 \mathrm{~cm} * 2 \mathrm{~cm}$, which was used as soil, was sifted to 
eliminate clumps of large size and discharged into a pot with thickness of around $6 \mathrm{~cm}$. Sample was buried below $4 \mathrm{~cm}$ of soil, under ambient temperature $\left(\sim 25^{\circ} \mathrm{C}\right)$. The films were removed at different times.

\section{Results and Discussion}

\section{Selection of level of ingredients}

To select the level of ingredients, first, preliminary trials were taken for its film formation. It was based on the hypothesis that the level of ingredients, which were used to form good films, would also form a good biodegradable cup. Numerous trials were conducted as their result of formulations selected is given below.

Effect of viscosity parameters of the slurry for biodegradable cup formation

To decide upon the pasting temperature properties of the raw material to form a standable biodegradable cup, rapid visco analyser was used as given in section 3.5. The pasting temperature of the selected formulation varied from $80.36 \pm 1.05^{\circ} \mathrm{C}$ to $85.85 \pm 2.05{ }^{\circ} \mathrm{C}$ and these were significant at $5 \%$ level of significance those they were no significant difference between the third and fourth samples, i.e. third sample was corn starch 7\%, Whey Protein Concentrate $2 \%$, Carboxymethyl cellulose $2 \%$ and the fourth sample was corn starch 7\%, Whey Protein Concentrate 1\%, Carboxymethyl Cellulose $2 \%$. The peak viscosity, i.e. the maximum viscosity that a formulation can attain was also a difference for all the samples it was found that the purest form the, i.e. corn starch has the highest peak viscosity, and the peak viscosity for other three samples was comparable at $5 \%$ level of significance. Now the formations of the cup happened at the final viscosity, i.e. the viscosity which was attained at the end of the formulation which does not change after that, so layering was done at this final viscosity the final viscosity for the 2,3and 4 sample was $1820 \pm 0.03 \mathrm{cP}, 1851 \pm 0.2 \mathrm{cP}, 1891 \pm 2.0 \mathrm{cP}$. The peak temperature at which this final viscosity was attained is $50-60^{\circ} \mathrm{C}$. It was concluded from the study that the temperature at which layering has to be done 50 to $60{ }^{\circ} \mathrm{C}$ and the final viscosity of the sample was checked at the set temperature again the impact of whey protein concentrate addition on the final viscosity of the sample, in which it is found that as the Whey protein concentrate content increased and the final viscosity decreased. After deciding upon the pasting properties, it was concluded that the layering has to be done at final viscosity from each formulation after that number of samples were tried which consist of a combination of corn starch, Whey Protein Concentrate, Glycerol, Carboxy Methyl Cellulose and given in Table 2.

Effect of number of layers on thickness and standability of biodegradable cup

The numbers of layers were also increased from 49 , and cup formation was checked and the combination for formulations is given in table 3 . The number of layers were assessed for thickness, and with the increase in the number of layers, the thickness increased significantly. In cases 4 layers thickness ranged from 0.09 to $0.15 \mathrm{~mm}$., 5 layers thickness formed 0.17 to $0.21 \mathrm{~mm}, 6$ layer thickness from range 0.23 to $0.35 \mathrm{~mm}, 7$ layer thickness ranged from 0.35 to $0.42 \mathrm{~mm}$, 8layers thickness ranged from 0.41 to $0.47 \mathrm{~mm}$ and 9 layer thickness ranged from 0.49 to $0.52 \mathrm{~mm}$ for sample 1 , to sample 3 respectively.

Table 1. Development of biodegradable cup using difference level of corn starch, whey protein concentrate, glycerol and carboxy methylcellulose

\begin{tabular}{|l|l|l|}
\hline SN & Combination & Observation \\
\hline $\mathbf{1}$ & Corn starch (7\%), WPC-35(2\%), CMC (2\%), Glycerol (2.5\%) & Good film \\
\hline $\mathbf{2}$ & Corn starch (7\%), WPC-35(3\%), CMC (2\%), Glycerol (2.5\%) & Good film with air bubbles \\
\hline $\mathbf{3}$ & Corn starch (7\%), WPC-35(3\%), CMC (2\%), Glycerol (4\%) & $\begin{array}{l}\text { Good film as per color, flexibility, } \\
\text { homogeneity of starch protein matrix }\end{array}$ \\
\hline $\mathbf{4}$ & Whey protein concentrate (7\%), glycerol (3\%) & $\begin{array}{l}\text { Brittle } \\
\text { Yellowish } \\
\text { Granulated film formation }\end{array}$ \\
\hline $\mathbf{5}$ & Corn starch (7\%), glycerol (3\%) & Thin, Transparency \\
\hline
\end{tabular}


Table 2. Pasting temperature, peak viscosity, final viscosity of selected samples

\begin{tabular}{|l|l|l|l|}
\hline Formulations/ Parameter & PT $\left({ }^{\circ} \mathbf{C}\right)$ & PV $(\mathbf{c P})$ & FV $(\mathbf{c P})$ \\
\hline CS (7\%) & $80.36 \pm 1.05^{\mathrm{d}}$ & $2877.00 \pm 1.52^{\mathrm{a}}$ & $2853.66 \pm 0.03^{\mathrm{a}}$ \\
\hline CS (7\%) + WPC-35 (3\%)+MC (2.0\%) & $85.10 \pm 1.34^{\mathrm{c}}$ & $1896.66 \pm 1.21^{\mathrm{d}}$ & $1820 \pm 00.3^{\mathrm{d}}$ \\
\hline CS (7.0) + WPC-35 (2.0\%)+MC (2.0)* & $85.80 \pm 1.8^{\mathrm{ab}}$ & $1963 \pm 0.08^{\mathrm{d}}$ & $1851 \pm 00.2^{\mathrm{c}}$ \\
\hline CS (7.0)+WPC-35 (1.0\%)+MC (2.0)* & $85.85 \pm 2.05^{\mathrm{a}}$ & $1980 \pm 0.08^{\mathrm{b}}$ & $1891 \pm 2.08^{\mathrm{b}}$ \\
\hline
\end{tabular}

It was observed that no cup was formed when 4 layers or 5 layers put on the cup and for 6 layers in certain formulations crack developed on the cup. Successful formation of the cup happened after 7 layers of the slurry was coated on it and the best formulation was when the 9 layers were coated for the cup formation's based on the visual selection of the cup the sample 3 was found to be desirable characteristics i.e. corn starch (7\%), Whey Protein Concentrate (3\%), CMC (2\%), and glycerol (2.5\%). Sample 2 was corn starch (7\%), Whey Protein Concentrate (2\%), Carboxymethyl Cellulose $(2 \%)$, and glycerol (2.5) \% and sample 3 was e corn starch (7\%), Whey Protein Concentrate (3\%), Carboxymethyl Cellulose (2\%), and glycerol $(4 \%)$.out of this best combination was the sample 3 in which the cup was clear, standable and flexible. The temperature for the formation of all 3 cups was kept at $60{ }^{\circ} \mathrm{C}$, and it normally took the drying time of $4 \mathrm{hrs}$ in total for the formation of the cup, and it was observed the capacity 55.1 to $55.7 \mathrm{ml}$ for the biodegradable cup. The number of layers was standardised to 9, which helped in the flexible formation of the cup .which did not collapse at the end. The pictorial view of the selected sample has been shown in Figure 2.

\section{Color analysis of biodegradable cup}

The biodegradable cup prepared by using Corn starch, Whey protein concentrate (WPC), carboxymethyl cellulose (CMC), glycerol at different concentration were analysed for colour values in terms of lightness value. Lightness value (L-value) of the biodegradable cup is one of the important parameters in terms of consumer acceptability and appearance. Table 6 shows the Lvalues of the biodegradable cup. For corn starch film (control), it was observed that L- value (lightness) reduced from $30.76 \pm 0.01$ as the concentration of starch increases from with the augmentation in the thickness of cup. It was also observed that there is a non-significant difference in $a$ and $b$ values of the cups, the findings are in concordance with outcomes described by Zavareze et al. (2012) for potato starch films. Significant rise $(p<0.05)$ in colour difference $(\Delta E)$ was found in corn starch films was as the concentration of starch augments. For composite biodegradable cup, L value reduced from $36.76 \pm 1.63$ to $41.96 \pm 1.86$ and the value of $\Delta \mathrm{E}$ increased, which might be due to the WPC addition. The colour of the cup became yellowish in appearance. The augmentation in these parameters may be attributed to maillard reaction takes place during processing between the corn starch and whey protein concentrate amino group. The yellowish colour associated with the interaction of protein-aldehyde was due to the maillard reaction of intermediated or final products (Sun et al., 2013). The values of composite film colour are in concordance to outcomes of Sun et al. (2013).

\section{Moisture Content of biodegradable cup}

Table 4 shows the MC of the biodegradable cup. The average MC of simple protein films $(21.8 \%)$ was marginally more in comparison to composite films $(20.5 \%)$. Glycerol addition to film-forming slurry resulted in a more hydrophobic nature of films; therefore, the composite films should contain less moisture than the simple protein films, our results showed that sample 1(5.80) containing less glycerol $(2.5 \%)$ had lowest moisture content as compared to sample 3(7.74) which contains a high amount of glycerol $(4 \%)$ it can be due to the interactions of glycerol and amylose which leads to the formation of hydrogen bonds. This interaction also results in week inter as well as the intramolecular bond between starch molecules (Gutierrez et al., 2015). 
Table 3. Effect of number of layers on thickness and standability of biodegradable cup

\begin{tabular}{|c|c|c|c|c|c|c|c|c|c|c|c|c|}
\hline $\begin{array}{l}\text { No. of } \\
\text { Lavers }\end{array}$ & 4 & & 5 & & 6 & & 7 & & 8 & & 9 & \\
\hline Sample & $\mathrm{T}$ & $\mathrm{S}$ & $\mathrm{T}$ & $\mathrm{S}$ & $\mathrm{T}$ & $\mathrm{S}$ & $\mathrm{T}$ & $\mathrm{S}$ & $\mathrm{T}$ & $\mathrm{S}$ & $\mathrm{T}$ & $\mathrm{S}$ \\
\hline 1 & $0.09 \pm 0.002$ & collapsed & $0.17 \pm 0.009$ & Collapsed & $0.23 \pm 0.012$ & collapsed & $0.35 \pm 0.021$ & standability & $0.41 \pm 0.024$ & standability & $0.49 \pm 0.034^{\mathrm{c}}$ & Standability \\
\hline 2 & $0.12 \pm 0.005$ & collapsed & $0.19 \pm 0.008$ & Collapsed & $0.26 \pm 0.009$ & collapsed & $0.38 \pm 0.015$ & standability & $0.45 \pm 0.033$ & standability & $0.51 \pm 0.04^{b}$ & Standability \\
\hline 3 & $0.15 \pm 0.009$ & collapsed & $0.21 \pm 0.012$ & Collapsed & $0.35 \pm 0.16$ & collapsed & $0.42 \pm 0.020$ & standability & $0.47 \pm 0.023$ & standability & $0.52 \pm 0.025^{\mathrm{a}}$ & Standability \\
\hline
\end{tabular}

Where; T -Thickness (mm), S-Standability

Sample 1 - corn starch $(7 \%)$, whey protein concentrate $(3 \%)$, CMC- $(2 \%)$, Glycerol- $(2.5 \%)$

Sample 2 - corn starch $(7 \%)$, whey protein concentrate $(2 \%)$, CMC- $(2 \%)$, Glycerol- $(2.5 \%)$

Sample 3 - corn starch (7\%), whey protein concentrate $(3 \%), \mathrm{CMC}-(2 \%)$, Glycerol- $(4 \%)$

Table 4. Functional characteristics of developed Biodegradable Cups.

\begin{tabular}{|c|c|c|c|c|c|}
\hline Parameter & Moisture Content wb (\%) & Thickness (mm) & Solubility (\%) & L value & WVTR $\left(\mathrm{g} / \mathrm{m}^{2} / \mathrm{h}\right)$ \\
\hline Sample 1 & $5.78 \pm 0.22^{\mathrm{c}}$ & $0.49 \pm 0.034^{\mathrm{c}}$ & $60.8-6$ & $36.76 \pm 1.63^{c}$ & $1.76 \pm 0.075^{\mathrm{a}}$ \\
\hline Sample 2 & $6.74 \pm 0.21^{\mathrm{b}}$ & $0.51 \pm 0.04^{b}$ & $50.54 \pm 3.08^{b}$ & $40.29 \pm 2.05^{\mathrm{b}}$ & $1.18 \pm 0.069^{b}$ \\
\hline Sample 3 & $7.74 \pm 0.16^{\mathrm{a}}$ & $0.52 \pm 0.025^{\mathrm{a}}$ & $48.50 \pm 0.66^{\mathrm{c}}$ & $41.96 \pm 1.86^{\mathrm{a}}$ & $1.14 \pm 0.086^{\mathrm{c}}$ \\
\hline
\end{tabular}

Sample $1-$ CS $(7 \%)+$ WPC-35 (3\%)+CMC (2\%)+GLY $(2.5 \%)$,

Sample 2 - CS $(7 \%)+$ WPC-35 $(2 \%)+$ CMC $(2 \%)+$ GLY $(2.5 \%)$

Sample 3 - CS (7\%)+WPC-35 (3\%)+CMC (2\%)+GLY (4\%),
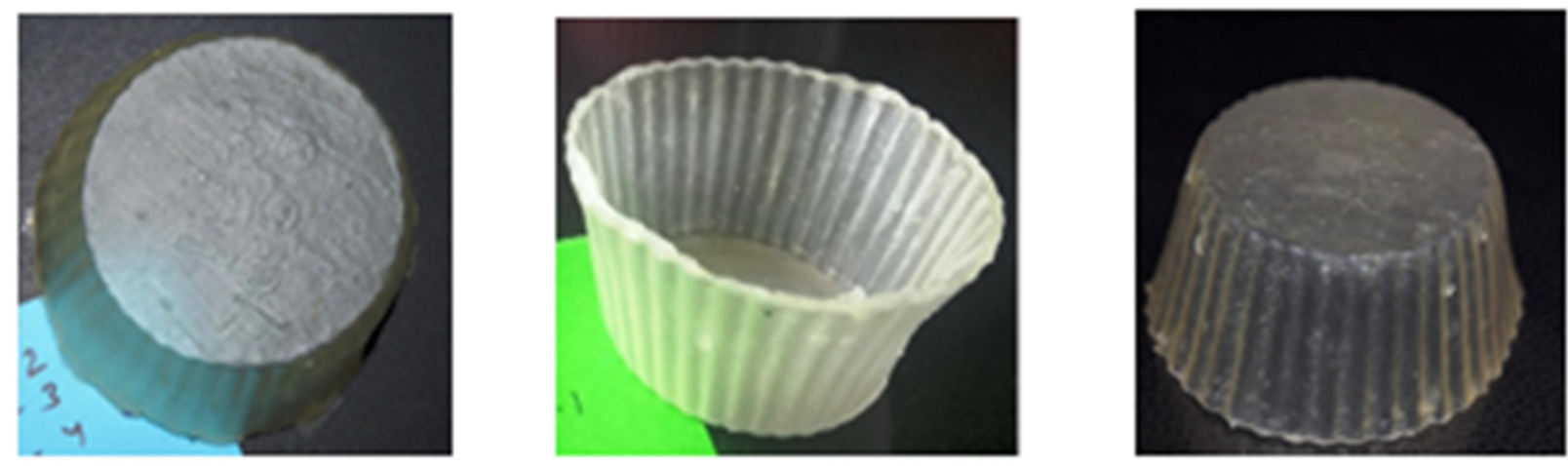

Figure 2. Three side view of Selected biodegradable cup (Corn Starch (7\%), Whey protein concentrate WPC-35 (3\%), Carboxymethyl cellulose (2\%), glycerol (4\%)) 


\section{Solubility of biodegradable cup}

Table 4 epitomises the solubility of biodegradable cup decreased from sample1 $(60.08 \pm 0.10)$, sample $2(50.54 \pm 3.43)$ and sample $3(48.50 \pm 0.66)$ at ambient temperature. All samples had significantly different values of solubility at a 5\% level of significance. The solubility of the film developed whey protein concentrate was significantly less in comparison to the developed corn starch. It is an essential parameter that is used to protect food with water-activity of higher value, prevents the exudation of frozen or fresh products during processing and maintains the food reliability (Gontard et al., 1992). The solubility of corn starch films reduces as the concentration of starch rises and the ratio of starch: glycerol reduces. Cuq et al. (1996) stated that the plasticiser's hydrophilic nature weakens the biopolymer molecules interactions and enhances solubility, leading to more amount of water attracted into the polymer matrix and produces more mobile regions with longer inter-chain distances. The lower solubility value was observed in the composite biodegradable film than corn starch film; this may be due to interactions between molecules among corn starchWPC-CMC forming the polymeric matrix. After dipping in water, the biodegradable composite film remained intact. The declined value of solubility may have arisen from interaction among free sulfhydryl (SH) protein group and free hydroxyl starch group also for the development of ester and hydrogen bonds between the carboxyl and hydroxyl groups of psyllium hydrocolloid. The values of composite biodegradable film solubility are similar with those of rice starch-chitosan, corn starch-CMC film, pea starch-peanut protein isolate blend and cassava starch-CMC film (Tongdeesoontorn et al., 2011; Ghanbarzadeh et al., 2010; Chinma et al., 2012; Sun et al., 2013) it might due to intense interaction between molecules among different components forming a polymeric matrix. In order to improve the shelf stability and moisture barrier properties, biodegradable films require water insolubility (Zavareze et al., 2012).

\section{Water vapour permeability of biodegradable} cup

Water is the primarily responsible factor for degrading reactions and textural alterations in food that influence the stability and quality of foods. Thus, to overcome these losses, there is a need to obstruct the transfer of moisture between environment and food; hence water vapour permeability of packaging films should be low for several applications. Table 4 shows water vapour permeability of composite biodegradable cup from sample 1(1.76 \pm 0.075$)$, sample 2(1.18 \pm 0.069$)$ and sample $3(1.14 \pm 0.086)$. All the samples had significantly different water vapour permeability at a $5 \%$ level of significance, as shown in table 4 . For corn starch films, decrease in water vapour permeability with augmentation in the concentration of starch was observed. This might be attributed to the rise in the concentration of starch, the ratio of starch: glycerol reduces. Adding plasticiser contributes to reorganisation network of the polymer that leads to an improvement in free volume and a less compact structure. As a result, space for water and other molecules increases so they can move throughout the matrix. However, the value of plasticiser ratio is lower, which leads to the decreased value of water vapour permeability with the rise in starch concentration. These outcomes were further confirmed by the lower value of solubility and moisture (Table 6) of corn starch films for higher values of concentration of starch. Furthermore, the value of water vapour permeability is lower was observed in the case of the composite film in comparison to corn starch films against all concentrations of starch. The development of cross-linking of starch and protein along with the adaptation of psyllium husk in the form of filler in the polymeric matrix leads to suitable water vapour barrier properties of the composite film. The resultant process has a lower value of free volume and distribution of moisture across it. Almost similar investigations related to decrease in WVP of edible films prepared from cassava starch + soy protein concentrate, Salvia Hispanica + whey protein interaction, pea starch + peanut protein isolate, and whey protein isolate + gelatin + sodium alginate films have been earlier reported (Wang et al., 2010; Chinma et al., 2012; Munoz et al., 2012; Sun et al., 2013).

\section{Morphology of developed biodegradable cup}

It has been observed from the morphological investigation that biodegradable composite cup constructed with additional structural integrity has more compact and homogeneous structure. This is because of the intense interaction between the 
molecules; formation as well as entanglement of polymeric matrix continuous phase (Mali et al., 2002; Garcia et al., 2009) among corn starch, WPC, $\mathrm{CMC}$ and plasticiser. Some cracks were observed in sample 2, as shown in figure 3 . The selected sample, i.e. sample 3 had a uniform structure. Similar findings of prominent uniform matrices and integrity of structure were previous described by

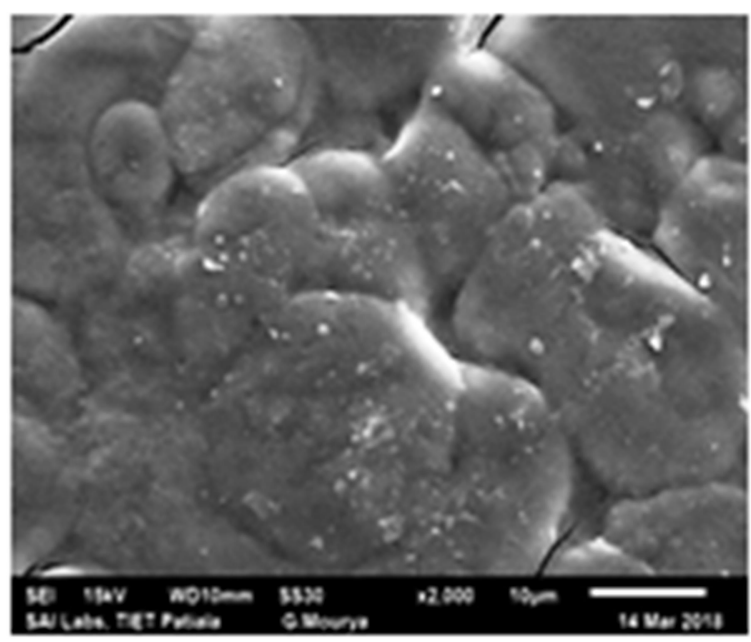

Dias et al. (2011) for cellulose fibre based films and rice flour. Compared to corn starch films, the composite biodegradable film uniformity in the polymeric matrix often helps for lowering the value of water vapour permeability which might be due to the lack of any voids on the film surface, thus decreasing the water binding sites availability.

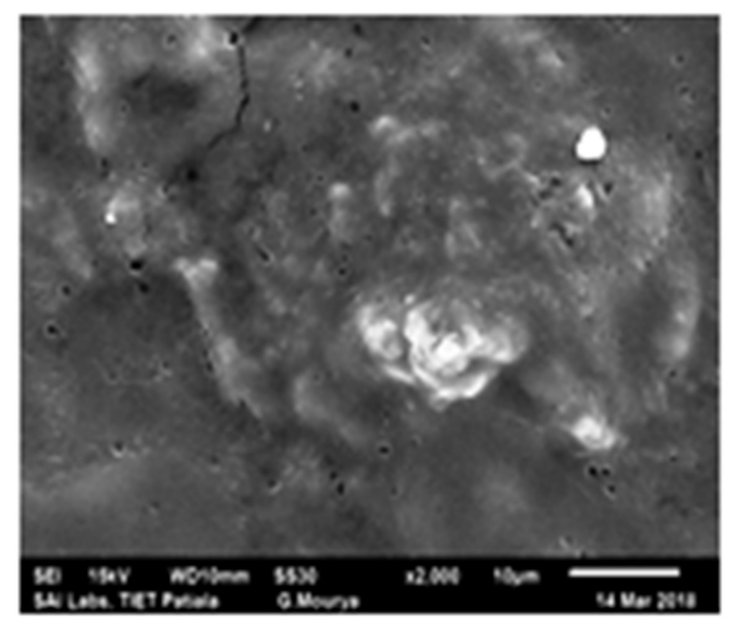

Fig. 3 Morphological images of Sample 2 (a) and Sample 3 (b)

\section{Degradation of biodegradable cup}

Biodegradability test was conducted for all three selected samples along with film made from corn starch (7\%) and glycerol $3 \%,($ sample A) and sample B (WPC-35-35 7\%, glycerol 3\%). In comparison, it was found sample $\mathrm{E}$ degraded at 55 days in vegetable compost whereas sample $\mathrm{C}$ and sample D biodegraded in 85 days. The degradation process of sample E was significantly faster than the other two samples. In soil, water diffuses into the samples with samples having higher glycerol percentage as water-soluble components dissolve quickly. Degradation was lower in sample $\mathrm{C}$ and sample D as it had more solid percentage. The result resonated with the observations reported by Maiti et al. (2012) according to which films having higher glycerol percentage biodegrade quickly.

\section{Conclusion}

The gradual social changes and observed megatrends occurring in the food chain has made packaging as one of the major components in marketing primary function of food packaging is to ensure the safety of the product and pressure it in good condition for the anticipated shelf life. In India, packaging has the largest application of plastic, i.e. $43 \%$ as compared to agriculture, auto factories and others. The use of plastic packaging has put a huge load on the environment, and the packaging of dairy products is also one of the major segments. Thus, the present investigation was carried out for the development of biodegradable cup for food packaging for development of biodegradable cup, base material like corn starch, carboxymethyl cellulose, whey protein concentrate and glycerol was selected. Various preliminary trials were conducted and yielded results were in the form of parameters like thickness, standability, and solubility was measured. Selection of ingredients for the formulation was done based on the review of literature and preliminary trials. Corn starch, whey protein concentrate were finalised. To form a biodegradable cup, following range was selected corn starch (5-8\%), whey protein concentrate $(1.5-3 \%)$, Carboxymethyl cellulose $(0.5-2.5 \%)$ and glycerol (2-4\%). For the formation of the cup, the viscosity of the formulation was important, so the selected formulation was analysed 


\section{Sonia et al.}

using rapid visco analyser. Peak viscosity, pasting temperature and final viscosity was noted as $1896.66 \pm 1.2,85.10 \pm 1.34$, and $1820 \pm 0.03$. For the development of biodegradable cup, layering method was selected after experimental runs and number of layers selected was 9 , which provided a thickness of $0.52 \pm 0.025 \mathrm{~mm}$ for the selected sample. The selected sample of the biodegradable

\section{References}

Averous, L. and Boquillon, N. 2004. Biocomposites based on plasticized starch: thermal and mechanical behaviours. Carbohydrate Polymers, 56(2): 111-122.

Chandla, N. K., Saxena, D. C. and Singh, S. 2017. Amaranth (amaranthus spp.) starch isolation, characterization, and utilization in development of clear edible films. Journal of Food Processing and Preservation, 41(6): 13217.

Chinma, C. E., Ariahu, C. C. and Abu, J. O. 2012. Development and characterization of cassava starch and soy protein concentrate based edible films. International Journal of Food Science and Technology, 47(2): 383-389.

Cuq, B., Gontard, N., Cuq, J. L. and Guilbert, S. 1996. Functional properties of myofibrillar protein-based biopackaging as affected by film thickness. Journal of Food Science, 61(3): 580-584.

Demirgöz, D., Elvira, C., Mano, J. F., Cunha, A. M., Piskin, E. and Reis, R. L. 2000. Chemical modification of starch based biodegradable polymeric blends: effects on water uptake, degradation behaviour and mechanical properties. Polymer Degradation and Stability, 70(2): 161170.

Dias, A. B., Müller, C. M. O., Larotonda, F. D. S. and Laurindo, J. B. 2011. Mechanical and barrier properties of composite films based on rice flour and cellulose fibers. LWT - Food Science and Technology, 44(2): 535-542.

Follain, N., Joly, C., Dole, P. and Bliard, C. 2005. Properties of starch based blends. Part 2. Influence of poly vinyl alcohol addition and photocrosslinking on starch based materials mechanical properties. Carbohydrate Polymers, 60(2): 185-192.

García, M., Hidalgo, J., Garmendia, I., and García-Jaca, J. 2009. Wood-plastics composites with better fire retardancy and durability performance. Composites Part A: Applied Science and Manufacturing, 40(11): 1772-1776.

Ghanbarzadeh, B., Almasi, H. and Entezami, A. A. 2010. Physical properties of edible modified starch/carboxymethyl cellulose films. Innovative Food Science and Emerging Technologies, 11(4): 697-702. cup was found to be having moisture content $7.74 \pm 0.16 \%$, and $\mathrm{L}$ value $41.96 \pm 1.8$. Biodegradability of samples was checked in the soil of $\mathrm{pH} 7.6$ and found that sample 3 (selected) degraded faster and became biodegradable in 55 days as compared to another sample, which took 85 days to biodegrade.

Gontard, N., Guilbert, S. and Cuq, J. L. 1992. Edible wheat gluten films: influence of the main process variables on film properties using response surface methodology. Journal of Food Science, 57(1): 190-195.

Gutiérrez, T. J., Morales, N. J, Pérez, E., Tapia, M. S. and Famá, L. 2015. Physico-chemical properties of edible films derived from native and phosphated cush-cush yam and cassava starches. Food Packaging and Shelf Life, 3: 1-8.

Jayasekara, R., Harding, I., Bowater, I., Christie, G. B. Y. and Lonergan, G. T. 2004. Preparation surface modification and characterisation of solution cast starch PVA blended films. Polymer Testing, 23: 17-27.

Laohakunjit, N. and Noomhorn, A. 2004. Effect of Plasticizers on Mechanical and Barrier Properties of Rice Starch Film. Starch-Starke, 56(8): 348-356.

Lourdin, D., Della, V. G., and Colonna, P. 1995. Influence of amylose content on starch films and foams. Carbohydrate Polymers, 27(4): 261-70.

Lu, Y., Tighzert, L., Dole, P. and Erre, D. 2005. Preparation and properties of starch thermoplastics modified with waterborne polyurethane from renewable resources. Polymer, 46(23): 9863-9870.

Maiti, S., Ray, D. and Mitra, D. 2012. Role of crosslinker on the biodegradation behavior of starch/polyvinylalcohol blend films. Journal of Polymers and the Environment, 20(3): 749-759.

Mali, S., Grossmann, M. V. E., Garcia, M. A., Martino, M. N. and Zaritzky, N. E. 2002. Microstructural characterization of yam starch films. Carbohydrate Polymers, 50(4): 379386.

Muñoz, L. A., Aguilera, J. M., Rodriguez-Turienzo, L., Cobos, A. and Diaz, O. 2012. Characterization and microstructure of films made from mucilage of Salvia hispanica and whey protein concentrate. Journal of Food Engineering, 111(3): 511-518.

Romero-Bastida, C. A., Bello-Pérez, L. A., García, M. A., Martino, M. N., Solorza-Feria, J. and Zaritzky, N. E. 2005. Physicochemical and microstructural characterization of films prepared by thermal and cold 
gelatinization from non-conventional sources of starches. Carbohydrate Polymers, 60(2): 235-244.

Sain, M. 2020. Production of bioplastics and sustainable packaging material from rice straw to eradicate stubble burning: A mini-review. Environment Conservation Journal, 21(3): 1-5.

Souza, A. C., Benze, R. F. E. S., Ferrão, E. S., Ditchfield, C., Coelho, A. C. V. and Tadini, C. C. 2012. Cassava starch biodegradable films: Influence of glycerol and clay nanoparticles content on tensile and barrier properties and glass transition temperature. $\boldsymbol{L W T}$-Food Science and Technology, 46(1): 110-17.

Sun, Q., Sun, C. and Xiong, L. 2013. Mechanical, barrier and morphological properties of pea starch and peanut protein isolate blend films. Carbohydrate polymers, 98(1): 630637.

Tongdeesoontorn, W., Mauer, L. J., Wongruong, S., Sriburi, P. and Rachtanapun, P. 2011. Effect of carboxymethyl cellulose concentration on physical properties of biodegradable cassava starch-based films. Chemistry Central Journal, 5(1): 1-8.

Wang, L., Auty, M. A. and Kerry, J. P. 2010. Physical assessment of composite biodegradable films manufactured using whey protein isolate, gelatin and sodium alginate. Journal of Food Engineering, 96(2): 199-207.

Xiao C. M. and Yang M. L. 2006. Controlled preparation ofphysical cross-linked starch-g-PVA hydrogel. Carbohydrate Polymer, 64: 37-40.

Zavareze, E. da R., Pinto, V. Z., Klein, B., El Halal, S. L. M., Elias, M. C., Prentice-Hernández, C. and Dias, A. R. G. 2012. Development of oxidised and heat-moisture treated potato starch film. Food Chemistry, 132(1): 344-350.

Zhai, M., Yoshii, F. and Kume, T. 2003. Radiation modification of starch-based plastic sheets. Carbohydrate Polymers, 52(3): 311-317.

Zhai, M., Yoshii, F., Kume, T. and Hashim, K. 2002. Syntheses of PVA/starch grafted hydrogels by irradiation. Carbohydrate Polymers, 50(3): 295-303. 